\title{
Nutrient content of macroalgae with differing morphologies may indicate sources of nutrients for tropical marine systems
}

\author{
Peggy Fong*, Krista Kamer ${ }^{* *}$, Katharyn E. Boyer ${ }^{* *}$, Karleen A. Boyle $^{* *}$ \\ Department of Organismic Biology, Ecology and Evolution, University of California, Los Angeles, 621 Charles E Young \\ Drive South, Box 951606, Los Angeles, California 90095-1606, USA
}

\begin{abstract}
To investigate whether tissue $\mathrm{N}$ and $\mathrm{P}$ content of morphologically distinct macroalgae reflect different processes controlling nutrient availability, we measured water column nutrients and collected 5 species of algae for tissue $\mathrm{N}$ and $\mathrm{P}$ analysis from 18 stations along the southwestern coast of Puerto Rico. Nutrient content of sediments was also determined for a subset of stations. Southwestern Puerto Rico was chosen because the literature suggests that gradients in sediment type and organic matter content, advection, and terrestrial influence occur in this region. Stations were either inshore or offshore areas with 3 stations per area chosen a priori as High Nutrient Stations (HNS). Water column and sediment nutrient concentrations were elevated inshore and in HNS. Species were of 3 morphological forms: upright thalli with open branches, densely packed mats, and rhizophytic thalli. In the first category, Acanthophora spicifera had higher N content inshore compared to offshore while both A. spicifera and Hypnea musciformis had higher tissue $\mathrm{N}$ and $\mathrm{P}$ contents in HNS. In contrast, mat-forming algae (Dictyota dichotoma and D. cervicornis) had higher tissue $\mathrm{N}$ and $\mathrm{P}$ contents offshore compared to inshore. Although these species had high nutrients in many of the HNS, samples from some offshore reefs were equally high. Halimeda incrassata, a rhizophytic form, had greater tissue $\mathrm{N}$ content inshore than offshore. H. incrassata tissue nutrients were also elevated in some HNS, but not others. There were significant correlations between water column and sediment nutrients and the tissue $\mathrm{N}$ and $\mathrm{P}$ content of $A$. spicifera and $H$. incrassata, but not for either Dictyota. These results suggest algae with upright thalli and open-branching patterns may have a more direct relationship between tissue nutrient content and water column nutrient concentration than other forms. In contrast, mat-forming species may deplete nutrients within the mat, relying on strong currents found offshore to penetrate dense mats and replenish nutrients. Rhizophytic algae have access to both water column and sediment nutrients, and higher inshore tissue contents and at some HNS may reflect enhanced nutrient supplies from these sources. Our findings suggest that if other environmental factors are carefully taken into consideration, the tissue $\mathrm{N}$ and $\mathrm{P}$ content of macroalgae may prove to be an effective indicator of different nutrient sources in tropical systems.
\end{abstract}

KEY WORDS: Macroalgae $\cdot$ Tropics $\cdot$ Nutrients $\cdot$ Morphological forms $\cdot$ Puerto Rico Resale or republication not permitted without written consent of the publisher

\section{INTRODUCTION}

Macroalgae common in shallow tropical waters have a wide diversity of morphologies including filamen-

\footnotetext{
*E-mail: pfong@biology.ucla.edu

${ }^{* *}$ Contribution of last 3 authors was equal, with order of authorship determined randomly
}

tous, sheet-like, foliose, coarsely branched and calcified forms (Littler \& Littler 1980, 1985, Steneck \& Watling 1982). They occur in many habitats such as coral reefs, lagoons, seagrass beds, and associated with mangrove roots (Littler et al. 1989, Littler \& Littler 2000). Productivity, growth, biomass accumulation, and the structure of tropical algal communities are controlled by many environmental factors and biotic 
interactions including temperature and light (e.g. Alves De Guimaraens \& Coutinho 1996, Beach \& Smith 1997, Bischoff-Baesmann et al. 1997), nutrients (e.g. Littler \& Littler 1985, Lapointe 1987, Lapointe \& O'Connell 1989), herbivory (e.g. Carpenter 1986, Szmant 1997, Russ \& McCook 1999), and competition (e.g. Hughes 1989, Tanner 1995, McCook 1999).

Limited availability of inorganic nitrogen (N) and phosphorus (P) (Lapointe 1987, Corredor et al. 1999) has been identified as important in determining distribution, productivity, and biomass accumulation of tropical algae (Hatcher \& Larkum 1983, Littler \& Littler 1985, Lapointe 1987, Lapointe et al. 1987, 1997, Lapointe \& O'Connell 1989, Schaffelke \& Klumpp 1997, 1998a,b). Traditionally, nutrient availability has been estimated by monitoring water column nutrient concentrations (Boynton et al. 1982, Howarth 1988, Cadée \& Hegeman 1993, Kress \& Herut 1998). Many laboratory experiments have related nutrient uptake, tissue nutrient content, and growth to water column nutrient content (e.g. Hanisak \& Harlin 1978, Hanisak 1983, Rosenburg \& Ramus 1984). These relationships were also documented in a combined field/laboratory experiment, where other factors such as advection were carefully controlled (Lapointe 1987), and for algae placed along an estuarine gradient (Horrocks et al. 1995). However, field studies in tropical regions suggest there is usually little correlation between ambient water column $\mathrm{N}$ or $\mathrm{P}$ concentrations and either productivity or abundance of primary producers (for a review see McCook 1999). Low correlation may be due to many nutrient processes, including pulsed nutrient supplies that are spatially and temporally variable (Genin et al. 1995, Diaz \& Ward 1997), rapid nutrient uptake by primary producers (Uthicke \& Klumpp 1998), and tightly coupled recycling between reef organisms (Larned \& Stimson 1997, Schaffelke \& Klumpp 1998b). Because of this lack of correlation, water column nutrients alone may not always provide an adequate indicator of nutrient supply or bioavailability in tropical systems (McCook 1999).

Measuring nutrient availability, especially at the scale relevant to primary producers, is difficult because availability is controlled by several complex physical and chemical processes. One physical control on nutrient supply is proximity to terrestrial sources of nutrients such as springs (Lapointe et al. 1997), fringing mangrove systems (Lapointe et al. 1987), and river mouths (Nixon et al. 1996, Corredor et al. 1999). Many activities associated with development of terrestrial systems (e.g. deforestation, agriculture, sewage disposal) increase transport of nutrients to marine habitats (Nixon et al. 1996, Jaworski et al. 1997, Vitousek et al. 1997, Corredor et al. 1999, Downing et al. 1999). Other physical processes affecting availability of $\mathrm{N}$ and $\mathrm{P}$ are advective supply and turbulent mixing across boundary layers (Atkinson \& Bilger 1992, Baird \& Atkinson 1997, Larned \& Atkinson 1997, Thomas \& Atkinson 1997). These processes may be especially important offshore, where rapid water motion is often coupled with low water column nutrient concentrations (Larned \& Atkinson 1997). Closer to shore, advection may be lower, but water column nutrient supplies may be supplemented by terrestrial or sediment sources (Lapointe \& O'Connell 1989, Larned \& Stimson 1997). One chemical process important in determining nutrient availability is adsorption of $\mathrm{P}$ to carbonate sediments; adsorption may contribute to low and variable $\mathrm{P}$ availability in the water column of shallow tropical areas (Delgado \& Lapointe 1994, McGlathery et al. 1994, Knoppers et al. 1996, Corredor et al. 1999). However, even for carbonate sediments with large capacities for P adsorption, sustained high levels of P loading into a system will result in a proportionately higher amount of P being biologically available (McGlathery et al. 1994, Corredor et al. 1999).

Recent investigations suggest that the tissue $\mathrm{N}$ and $\mathrm{P}$ content and N:P ratio in the tissue of marine macroalgae have potential as indicators of nutrient availability (Wheeler \& Björnsäter 1992, Fong et al. 1998, McCook 1999). In an early investigation, Atkinson \& Smith (1983) concluded that C:N:P ratios in macroalgae and seagrasses collected from low-nutrient tropical areas were significantly different from those in high-nutrient temperate areas. Björnsäter \& Wheeler (1990) linked tissue $\mathrm{N}$ and $\mathrm{P}$ content to nutrient supplies in laboratory cultures of macroalgae. Based on these results, they used the $\mathrm{N}: \mathrm{P}$ ratios of field collected algae to determine seasonal changes in $\mathrm{N}$ and $\mathrm{P}$ limitation (Wheeler \& Björnsäter 1992). Fong et al. (1994) developed a quantitative relationship between nutrient supply and tissue $\mathrm{N}$ and $\mathrm{P}$ content of an opportunistic green macroalga. This relationship was used to develop and test a bioindicator of nutrient supply in the field for southern California (Fong et al. 1998). Results of these studies suggested that tissue $\mathrm{N}$ and $\mathrm{P}$ contents and $\mathrm{N}: \mathrm{P}$ ratios of macroalgae may be more useful than traditional water quality sampling for estimating biologically available pulses of nutrients (Horrocks et al. 1995, Fong et al. 1998).

In this paper, we investigated the potential for tissue $\mathrm{N}$ and $\mathrm{P}$ content and the N:P ratio of common species of morphologically divergent macroalgae to be used as an indicator of different processes controlling nutrient availability to macroalgae across several tropical habitats. We hypothesize that nearshore habitats have greater nutrient supplies to the water column and therefore algae associated with the water column that are collected nearshore will have higher nutrient content. Sediments have been identified as an important 
source of nutrients to tropical algae with bulbous holdfasts and rhizoids that anchor in sediments (Williams 1981, Larned 1998). We hypothesize that rhizophytic algae will have higher nutrient content in inshore areas with larger water column and sediment nutrient pools. In contrast, for algae that form densely compacted mats, we hypothesize that rates of flow (advection) may be especially important in controlling nutrient availability, uptake, and storage because reduction of flow within mats forms large nutrient-depleted boundary layers. Thus, mat-forming algae in high flow areas should have greater tissue nutrients than mats in low flow areas.

\section{METHODS}

Study area. We chose to sample the southwestern coast of Puerto Rico (Fig. 1) because the literature suggests that gradients in sediment type and organic matter content, advection, and terrestrial influence occur in this region (Odum et al. 1959, Morelock et al. 1977, Breyer \& Ehlmann 1981, Rafalska-Bloch 1985). All of our sampling stations are in the inner and middle shelf regions identified by Morelock et al. (1977); the inner shelf is further divided based on sediment types and geomorphology. Morelock et al. (1977) found that mangrove dominated coasts and shallows contain mostly fine-grained carbonates, while sediments from areas further from shore contain sandy silt to sand in seagrass beds and are very coarse-grained around reefs. Sediment organic matter also changes along an onshore-offshore gradient (Rafalska-Bloch 1985), with highest organic content along mangrove-dominated coasts $(3.15 \%)$, then abruptly decreasing as you move offshore to seagrass beds $(0.62 \%)$ and reef lagoons $(0.47 \%)$. Both inner and middle shelf reef sediments had very low organic content $(0.16 \%)$.

Rafalska-Bloch (1985) describes southwestern Puerto Rico as an open coast because the lack of a shallow barrier reef allows relatively high water flow everywhere across the shelf. Depositional energy is very high around patch reefs, intermediate over seagrass beds and lagoons, and is low only in coastal mangrove areas (Rafalska-Bloch 1985). Early work established that advection, measured as current speed, also varied between inshore and offshore regions of equal depth (Odum et al. 1959); in a study measuring current speed in winter, spring and summer, inshore currents ranged from 0 to $4.2 \mathrm{~m} \mathrm{~min}^{-1}$ while offshore speeds were 5 to $9 \mathrm{~m} \mathrm{~min}^{-1}$.

Southwestern Puerto Rico is semi-arid, with a rainy season from September through October (Morelock et. al. 1977). We sampled in the dry season from 15 to 29 January 1998. There was measurable rainfall on 5 of 15 sampling days $(15,20,25,26$, and 29 January) for a total of $0.20 \mathrm{~cm}$ (NOAA rainfall data 1959 to 1998 for Magueyes Island). All of January 1998 was relatively dry with a total of $0.78 \mathrm{~cm}$ of rain compared to the $40 \mathrm{yr}$ average of $1.38 \mathrm{~cm}$ (NOAA rainfall data 1959 to 1998 for Magueyes Island). The prior rainy season was also relatively dry, with a total of $5.00 \mathrm{~cm}$ in September and October of 1997 compared to the $40 \mathrm{yr}$ average of $8.84 \mathrm{~cm}$ (NOAA rainfall data 1959 to 1998 for Magueyes Island). As all of the major drainages for inland portions of the island are to the east of our sampling sites (Bryer \& Ehlmann 1981), terrestrial runoff to inshore stations is from local sources, not inland where rainfall can be considerably higher.

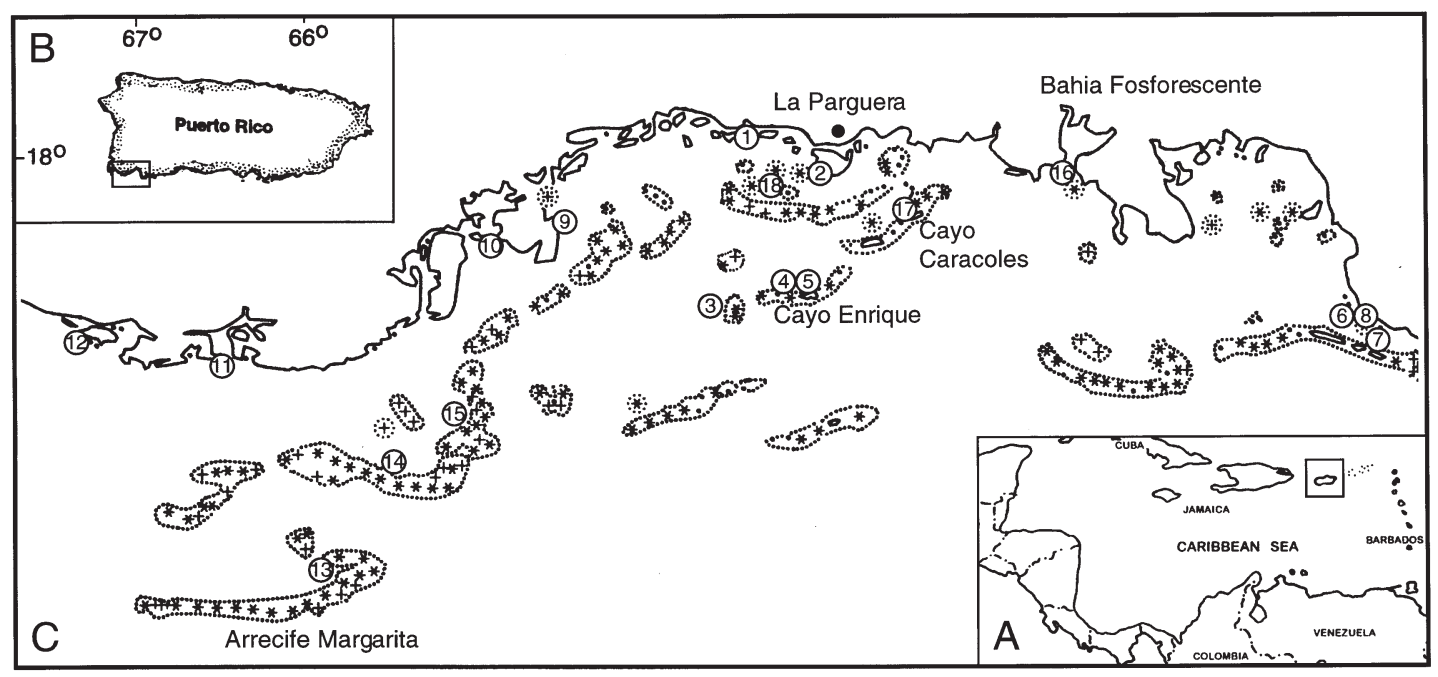

Fig. 1. Map of: (A) the Caribbean Sea outlining Puerto Rico; (B) Puerto Rico identifying the sampling area; and (C) the 18 sampling stations off the SW coast of Puerto Rico. In southwestern Puerto Rico, the prevailing wave direction is from the southeast and the prevailing current moves from east to west along the shore 
We visited 18 sampling stations along the southwestern coast of Puerto Rico (Fig. 1). Sampling stations were grouped into 2 categories. Inshore stations were within $10 \mathrm{~m}$ of the main island in mangrove, seagrass habitats, or rubble (Stns 1, 6, 7, 8, 9, 10, 11, 12 and 16) or offshore of the main island in mangrove and seagrass habitats (Stns 2, 5, 15, 17 and 18) and shallow reefs (Stns 3, 4, 13 and 14). Stations were established both east and west of the town of La Parguera. Stations were as uniform in depth as possible (1 to $3 \mathrm{~m}$ ), and care was taken to collect in areas that were not shaded.

Some stations were chosen haphazardly, but others were selected a priori as potential High Nutrient Stations (HNS). Inshore HNS included Stns 1, 11 and 16. Secondary sewage effluent is released into percolation ponds adjacent to the fringing mangroves in La Parguera (Corredor \& Morell 1994). Stn 1 was within $10 \mathrm{~m}$ of this potential nutrient source. Stn 11 was inside an embayment that had lower carbonate content compared to our other inshore areas (Jacobson \& Fong unpubl. data); these sediments may be a source of terrestrial nutrients. Stn 16 was at the mouth of Bahia Fosforescente; the benthic communities in the fringing areas of this bay were found to be highly productive (Odum et al. 1959) and have sediments with high organic content $(2.79 \%$; Rafalska-Bloch 1985) suggesting this may be an area with enhanced nutrient supply. Stations chosen as potential offshore HNS included Stns 15, 17, and 18. Stn 15 was a mangrove island used extensively by local fishermen as a fish cleaning station. Refuse is dropped into the water on a daily basis, and was observed in various states of decay on the benthos at the time of collection. We hypothesize that degradation processes released significant amounts of nutrients at this station. Stn 17 was in the lee of an island where several live-aboard sailboats anchor. Typically these boats release untreated wastewater directly into the ocean. Stn 18 was off an island with a large bird rookery. Dense aggregations of birds have been documented to be a nutrient source to nearby shallow marine habitats (Powell et al. 1989).

Water column and sediment nutrients. Water samples were collected at each of the 18 stations concurrent with algal collections. Care was taken to collect water samples near the benthos, just above the algae. Water samples were placed on ice in a dark cooler immediately after collection, returned to the lab within $3 \mathrm{~h}$, filtered with Whatman GF/C filters, and frozen. Frozen samples were packed in dry ice in a cooler and sent to DANR Analytical Lab. at the University of California Davis. We confirmed with the lab that samples arrived the next day, and were still frozen. Water samples were analyzed for Total Kjeldahl Nitrogen (TKN), $\mathrm{NO}_{3}, \mathrm{NH}_{4}$, and total phosphate (TP). The TKN method is based on the wet oxidation of nitrogen using sulfuric acid and digestion catalyst. The procedure converts organic nitrogen to the ammonium form and subsequent determination of ammonium. The procedure does not quantitatively digest nitrogen from heterocyclic forms (bound in a carbon ring), or from oxidized forms such as nitrate and nitrite. Ammonium and nitrate are measured by the diffusionconductivity method as described by Carlson (1978) based on the gaseous diffusing of ammonia $\left(\mathrm{NH}_{3}\right)$ across a gas permeable membrane in the presence of excess base $(\mathrm{KOH})$ and subsequent conductivity detection. Total phosphorous in seawater is measured utilizing a nitric $\mathrm{acid} /$ hydrogen peroxide microwave digestion (Johnson \& Ulrich 1959). Subsequently, the analyte concentration is determined by Inductively Coupled Plasma Atomic Emission Spectrometry (ICP-AES) with a vacuum spectrometer (Franson 1985). These automated methods have detection limits of $3.57 \mu \mathrm{M}$ for $\mathrm{N}$ and $1.56 \mu \mathrm{M}$ for $\mathrm{P}$. Many of the 54 samples taken were below these detection limits. Number of samples below detection were 2 for TKN, 49 for $\mathrm{NH}_{4}, 3$ for $\mathrm{NO}_{3}$, and 19 for TP.

Sediment samples were taken at 8 of the 18 stations in Sep 1998, 8 mo after the water and algal samples were collected. Ideally, sediment samples would have been taken concurrently with other sampling. However, as this was not possible at the time, we used these later samples for comparison. Sediment cores $(5 \mathrm{~cm}$ deep) were taken with $60 \mathrm{ml}$ syringes (inner diameter $=2.5 \mathrm{~cm}$ ) with the end cut off and edges sharpened. Ten sediment cores were taken from each site; cores were haphazardly located within each collection site. Cores were stored on ice in the dark, returned to the lab within $3 \mathrm{~h}$, dried in a forced air oven $\left(<60^{\circ} \mathrm{C}\right)$ to constant wt (24 to $48 \mathrm{hr}$ ), ground with a mortar and pestle, and analyzed for TKN, total P, and P-Olsen content at DANR Analytical Lab. Total Kjeldahl Nitrogen in sediment is determined by measuring total reduced nitrogen after the wet oxidation of sediment organic matter using standard Kjeldahl procedure with sulfuric acid and digestion catalyst (Issac \& Johnson 1976, Carlson 1978). Total $P$ in sediments was determined by microwave acid digestion/dissolution of sample (Sah \& Miller 1992) followed by atomic emission spectroscopy. The detection limit of this method is $<0.010 \% \mathrm{P}$, resulting in 48 of 76 samples being below limits. P-Olsen is extractable phosphate based on alkaline extraction by 0.5 Normal $\mathrm{NaHCO}_{3}$. It measures available phosphate for sediments with $\mathrm{pH}$ greater than 6.5 by ascorbic acid reduction of phosphomolybdate complex and measurement by spectrophotometry (Olsen et al. 1954).

Algal collections. Five common species of algae were collected at as many of the 18 stations as they occurred. Algae were considered common based on visual observations of presence/absence during initial surveys over a wide variety of areas. Two congeneric species of brown algae (Division Chromophyta), Dictyota dicho- 
toma and Dictyota cervicornis, were collected. Thalli are thin, dichotomously branched flattened blades that are often formed into very dense, tightly packed mats on hard bottom, rubble, or coarse sand. For this study we only collected thalli of Dictyota that formed dense mats. Two species, Acanthophora spicifera and Hypnea musciformis, are red algae (Division Rhodophyta) with open-branching patterns compared to the matforming Dictyota. A. spicifera has a coarsely branched morphology with upright portions extending into the water column. It was often found growing epiphytically on the roots of mangroves. When collecting from mangrove roots, samples were only taken from the outermost, sunlit roots. In seagrass or reef habitats, $A$. spicifera was found growing on rubble or hard substrate. We only collected specimens that had open branches extending into the water column. $H$. musciformis is a more finely branched species that frequently epiphytized algae attached to rubble or hard bottoms. The fine branches usually extend into the water column above its host, and we restricted our collections to these samples. The fifth species, Halimeda incrassata is a psammophytic green alga (Division Chlorophyta) that is anchored in sandy substrates by a bulbous rhizoidal system that allows access to sediment nutrients (Littler et al. 1991). It also has an openly branched and upright thallus that is heavily calcified and extends up into the water column.

At each of the 18 stations we collected algal samples at 3 sites to test for within station variability. Each of the sites in a station was within $10 \mathrm{~m}$ of each other. At each site we attempted to collect 5 replicate samples of each alga. However, not all species of algae were found at each station or within each site in sufficient abundance to accomplish this goal. Because sample sizes were not always consistent within a station, we included sample sizes in every figure and table.

Within $3 \mathrm{~h}$ of collection, algal samples were carefully sorted to species and cleaned of sediments, macroinvertebrates, and epiphytes. Tissue was briefly rinsed in freshwater to remove salts, dried in a forced air oven $\left(60^{\circ} \mathrm{C}\right)$ to constant wt ( 24 to $48 \mathrm{~h}$ ), ground with mortar and pestle or a Wiley Mill, and analyzed for tissue N and $\mathrm{P}$ content. The heavy $\mathrm{CaCO}_{3}$ deposits in Halimeda incrassata result in less living tissue per gram wt. Because tissue $\mathrm{N}$ and $\mathrm{P}$ content is determined as a percentage of dry wt, tissue $\mathrm{N}$ and $\mathrm{P}$ values for $H$. incrassata should be lower than for the other species of algae collected in this study.

Algal samples were analyzed for tissue $\mathrm{N}$ and $\mathrm{P}$ content at DANR Analytical Lab using standard methods. The method for total $\mathrm{N}$ quantitatively determines the amount of nitrogen in all forms (ammonium, nitrate, protein and heterocyclic nitrogen) in botanical materials using an induction furnace and a thermal conductiv- ity detector. In this method, samples are ignited in a quartz combustion tube containing a helium and oxygen environment placed in an induction furnace at approximately $900^{\circ} \mathrm{C}$. An aliquot of the combustion gases is passed through a copper catalyst to remove oxygen and convert nitrous oxides to $\mathrm{N}_{2}$. The aliquot of combustion gases is then scrubbed of moisture and carbon dioxide. Finally, the nitrogen content is determined by thermal conductivity (Sweeney 1989). The method for total phosphorous quantitatively determines the concentration of phosphorous in botanical materials utilizing a nitric acid/hydrogen peroxide microwave digestion (Johnson \& Ulrich 1959). Subsequently, the analyte concentration is determined by Inductively Coupled Plasma Atomic Emission Spectrometry (ICP-AES) with a vacuum spectrometer (Franson 1985).

Data analysis. Data were tested to ensure that they conformed to the assumptions of parametric statistics; no transformations were required. Nested ANOVA did not find significant differences in mean $\mathrm{N}$ or $\mathrm{P}$ contents among sites within stations for any of the species of algae, so the nested factor (site within stations) was dropped from all subsequent analyses.

Single-factor ANOVA (factor = species) was used to identify differences in tissue N, P, and N:P ratios among the 5 species of macroalgae. All replicate samples for all stations for all algal species were used in this analysis. After a statistically significant ANOVA, differences in mean values among species were identified using a Protected Least Significant Difference (PLSD) test. This test is a conservative multiple comparison technique as it controls experiment-wise error; the unprotected test allows this error to increase with each comparison.

We used $t$-tests to determine if there were significant differences between mean water column nutrients, sediment nutrients, and $\mathrm{N}, \mathrm{P}$ and $\mathrm{N}: \mathrm{P}$ ratios in samples collected from inshore (Stns 1, 6, 7, 8, 9, 10, 11, 12 and 16) vs offshore (Stns 2, 3, 4, 5, 13, 14, 15, 17 and 18). For water and sediment samples, each independent sample (water bottle or sediment core) was used as a replicate, regardless of station. Statistical analyses were not conducted on sediment total P as only 3 of 28 samples collected offshore had total P contents above detection limits. In the tissue nutrient analysis, we compared all samples collected inshore to all samples collected offshore for each algal species separately, regardless of station. Inshore/offshore patterns were analyzed for 4 of 5 species of algae because Hypnea musciformis was only found in 1 offshore station, which we did not consider to be sufficient representation of offshore sites. For all comparisons there were greater sample sizes inshore compared to offshore. However, the relative proportion of samples from HNS were similar inshore and offshore as algae were usually abundant in these locations. 
Single-factor ANOVA was used to determine differences in water column and sediment nutrients among stations. Single-factor ANOVA (factor = station, with all samples collected within each station used as replicates) was also used to compare mean $\mathrm{N}$ and $\mathrm{P}$ contents and N:P ratios for 3 of the species (Acanthophora spicifera, Dictyota dichotoma, and Halimeda incrassata). This analysis was also conducted for Hypnea musciformis and Dictyota cervicornis, though, unlike the above analysis, these results are only reported in a table. We did not feel these results warranted both table and graph as these species were found with replication in less than half of the stations (8 and 5 stations, respectively). After a statistically significant ANOVA, differences among means were identified using a PLSDtest. Finally, correlations between water column, sediment and algal tissue nutrients were determined.
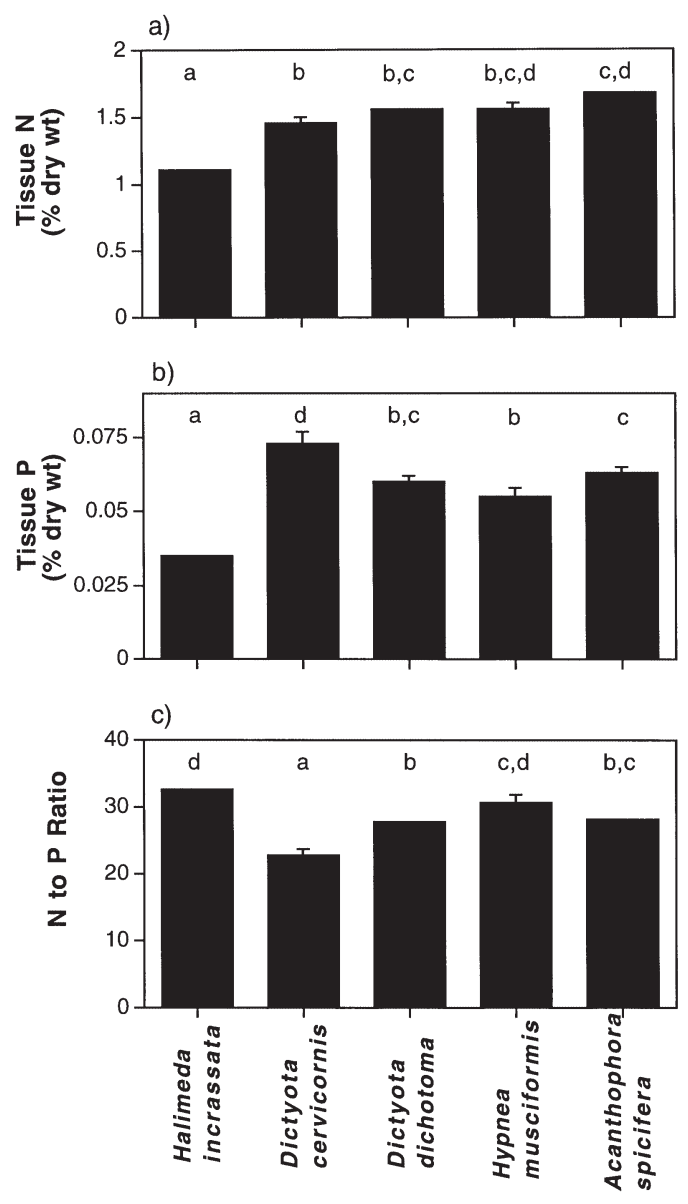

Fig. 2. Tissue (a) N, (b) $\mathrm{P}$, (c) N:P ratio in different species of algae collected in southwestern Puerto Rico (error bars = SE). Letters above the bars show the results of the PLSD; different letters distinguish significantly different means $(\mathrm{p}<0.05)$. Samples size for Acanthophora spicifera $=210$, Halimeda incrassata $=150$, Dictyota dichotoma $=133$, Dictyota cervicornis $=67$, and Hypnea musciformis $=39$

\section{RESULTS}

\section{Comparisons among species}

Tissue $\mathrm{N}$ differed significantly among the 5 species of algae collected (Fig. 2a; ANOVA p = 0.0001). As expected because of $\mathrm{CaCO}_{3}$ deposits (i.e. less living tissue per $\mathrm{g}$ of $\mathrm{wt}$ ), tissue $\mathrm{N}$ was lowest in Halimeda incrassata (PLSD $\mathrm{p}=0.0001$ for all comparisons). There were slight differences in tissue $\mathrm{N}$ contents among the other 4 species of algae, with Dictyota cervicornis lowest and Acanthophora spicifera highest.

Differences in mean P contents were also significant among the algal species (Fig. 2b; ANOVA p = 0.0001). There were proportionally larger differences among mean tissue $\mathrm{P}$ contents than $\mathrm{N}$ contents for the 5 species of algae. $\mathrm{P}$ content of Halimeda incrassata was lower than all other species (PLSD $p<0.001$ for all comparisons). P content of Dictyota cervicornis was the highest (PLSD $\mathrm{p}<0.003$ for all comparisons), about double that of $H$. incrassata. Among the 3 species of algae with intermediate P contents, Acanthophora spicifera ranked highest and Hypnea musciformis lowest. Tissue P content of Dictyota dichotoma was between these two, and not significantly different from either.

$\mathrm{N}$ : $\mathrm{P}$ ratios also differed among algal species (Fig. 2C; ANOVA $\mathrm{p}=0.0001)$. The N:P ratio of Dictyota cervicornis was lower than all others (PLSD p $=0.0001$ ) due to a high tissue $\mathrm{P}$ content. There was considerable overlap among the other 4 species with Halimeda incrassata ranked the highest and Dictyota dichotoma the lowest.

There were significant correlations between tissue $\mathrm{N}$ and $\mathrm{P}$ content for Acanthophora spicifera $(\mathrm{R}=0.847$, $\mathrm{p}=0.0001)$, Dictyota dichotoma $(\mathrm{R}=0.752, \mathrm{p}=0.012)$, Dictyota cervicornis $(\mathrm{R}=0.828, \mathrm{p}=0.0058)$, and Halimeda incrassata $(\mathrm{R}=0.829, \mathrm{p}=0.0005)$. Tissue $\mathrm{N}$ and $\mathrm{P}$ content did not correlate in Hypnea musciformis.

\section{Inshore versus offshore comparisons}

Mean TKN in water samples collected inshore was significantly higher than offshore (Table 1). No other measure of water column nutrients differed between inshore and offshore samples, though $\mathrm{NO}_{3}$ was close to significant. TKN in sediments inshore was more than triple that offshore (Table 1) while mean P-Olsen in sediments inshore was nearly double the offshore content. Only 3 offshore samples had TP above detection limits, so statistical analysis was not conducted. However, the low number of samples with measurable TP offshore compared to inshore suggest there is less $\mathrm{P}$ in offshore sediments. 
Acanthophora spicifera and Halimeda incrassata had similar inshore/ offshore patterns in tissue nutrient content (Table 1). Samples of both algae collected inshore had significantly higher tissue $\mathrm{N}$ than samples collected offshore around mid-shelf islands or reefs. This reflected elevated $\mathrm{N}$ in both the water and sediments inshore. Although extractable $\mathrm{P}$ in sediments was higher inshore, mean tissue $\mathrm{P}$ contents were not different between onshore and offshore stations for either species. Thus, N:P ratios for both species were higher inshore due to greater tissue $\mathrm{N}$ of inshore samples ( $t$-test $p=0.0001$ for both species).

Inshore/offshore patterns of $\mathrm{N}$ and $\mathrm{P}$ contents for the 2 species of Dictyota were similar to each other, but different from the other algal species (Table 1). Both species of Dictyota had higher N content offshore compared to inshore. Tissue $\mathrm{P}$ was also almost twice as high offshore compared to inshore for $D$. cervicornis. While mean tissue $\mathrm{P}$ was higher offshore for $D$. dichotoma, this difference was not significant. Mean $\mathrm{N}$ :P ratio for $D$. cervicornis was higher inshore than offshore. There were no differences in N:P ratios for $D$. dichotoma. Neither tissue $\mathrm{N}$ nor $\mathrm{P}$ contents reflected water column or sediment concentrations.

\section{Comparisons among stations}

There were no significant differences in water column TKN among stations (Table 2; ANOVA $\mathrm{p}=$ 0.0781). With the exception of the High Nutrient Stations (HNS), TKN was usually lower offshore than inshore. There were no patterns in mean water column TP among stations. However, there were significant differences in $\mathrm{NO}_{3}$ among stations (ANOVA $\mathrm{p}=0.0004$ ). Stn 1 (sewage ponds) and Stn 11 (low-carbonate bay) had higher $\mathrm{NO}_{3}$ than any of the other stations (PLSD p < 0.007 for all comparisons). These were inshore HNS. Bahia Fosforescente, another HNS, did not have elevated $\mathrm{NO}_{3}$. Although not statistically different due to high variability, $\mathrm{NO}_{3}$ concentrations in offshore HNS were higher than in other stations that were not HNS.

There was a significant difference in sediment TKN, $\mathrm{TP}$, and P-Olsen (ANOVA $\mathrm{p}=0.0001$ for all 3 comparisons) among stations (Table 3 ). Three of 5 inshore sta- tions (Stns 1, 9 and 11) had significantly higher TKN contents than other stations (PLSD $\mathrm{p}<0.006$ for all comparisons). In contrast, the 2 offshore stations that were not HNS (Stns 3 and 14) were an order of magnitude lower in TKN (PLSD p < 0.05). The offshore HNS (Stn 17) had significantly higher TKN than other offshore stations (PLSD $\mathrm{p}<0.05$ for both comparisons), but ranked with inshore stations that were not HNS. Sediment TP contents of offshore stations that were not HNS (Stns 3 and 14), as well as one inshore station (Stn 6), were always below detection limits (Table 3). Although the 2 HNS inshore (Stns 1 and 11) had high TP contents, another inshore station (Stn 9) that was not chosen a priori as a HNS also had high TP (PLSD $\mathrm{p}<0.006$ for all comparisons). For extractable $\mathrm{P}$ (P-Olsen), values ranked highest in the inshore HNS (1 and 11). In the rest of the stations, extractable $P$ decreased from the offshore HNS (Stn 17), to the inshore stations (Stns 6, 9 and 12), with the lowest values found in the offshore stations (Stns 3 and 14) (PLSD $\mathrm{p}<0.05$ for all comparisons). 
Table 2. Water column nutrient content for stations in southwestern Puerto Rico during Jan 1998. Where $\mathrm{n}<3$, other measures are below detection limits. High Nutrient Stations (HNS) are indicated by *

\begin{tabular}{|c|c|c|c|c|c|c|c|}
\hline Location & Stn & $\mathrm{TKN}(\mu \mathrm{M})$ & $\mathrm{n}$ & $\mathrm{TP}(\mu \mathrm{M})$ & $\mathrm{n}$ & $\mathrm{NO}_{3}(\mu \mathrm{M})$ & $\mathrm{n}$ \\
\hline Inshore $^{*}$ & 1 & $54.76(2.38)$ & 3 & - & & $15.00(5.77)$ & 3 \\
\hline Inshore* & 11 & 52.38 (8.59) & 3 & 2.345 & 2 & $18.33(5.24)$ & 3 \\
\hline Inshore ${ }^{*}$ & 16 & $30.95(2.38)$ & 3 & 1.560 & 1 & $4.53(0.24)$ & 3 \\
\hline Inshore & 6 & $52.38(8.59)$ & 3 & 2.190 & 1 & $4.05(0.24)$ & 3 \\
\hline Inshore & 7 & $42.86(18.90)$ & 3 & 1.560 & 2 & 3.93 & 2 \\
\hline Inshore & 8 & $59.52(17.17)$ & 3 & 1.560 & 1 & $5.00(0.41)$ & 3 \\
\hline Inshore & 9 & $52.38(15.51)$ & 3 & $1.773(0.107)$ & 3 & 3.93 & 2 \\
\hline Inshore & 10 & 21.43 & 1 & 2.190 & 1 & 3.57 & 1 \\
\hline Inshore & 12 & $28.57(8.25)$ & 3 & $1.880(0.000)$ & 3 & $4.29(0.41)$ & 3 \\
\hline Offshore* & 15 & $50.00(10.91)$ & 3 & $1.667(0.000)$ & 3 & $6.56(0.84)$ & 3 \\
\hline Offshore* & 17 & $35.71(25.08)$ & 3 & 1.720 & 2 & $6.45(0.83)$ & 3 \\
\hline Offshore* & 18 & $54.76(22.71)$ & 3 & 1.560 & 2 & $6.25(1.00)$ & 3 \\
\hline Offshore & 2 & $9.52(2.38)$ & 3 & $2.190(0.479)$ & 3 & $4.05(0.48)$ & 3 \\
\hline Offshore & 3 & $26.19(12.60)$ & 3 & 1.560 & 2 & $4.05(0.24)$ & 3 \\
\hline Offshore & 4 & $26.19(2.38)$ & 3 & $1.773(0.107)$ & 3 & $4.76(0.47)$ & 3 \\
\hline Offshore & 5 & $9.52(2.38)$ & 3 & 1.720 & 2 & $5.00(0.00)$ & 3 \\
\hline Offshore & 13 & $16.67(2.38)$ & 3 & $1.667(0.107)$ & 3 & $4.05(0.24)$ & 3 \\
\hline Offshore & 14 & $23.81(4.76)$ & 3 & - & & $4.05(0.24)$ & 3 \\
\hline
\end{tabular}

There were differences in tissue $\mathrm{N}$ contents of Acanthophora spicifera among stations (ANOVA $\mathrm{p}=$ 0.0001). HNS ranked high in tissue $\mathrm{N}$ regardless of
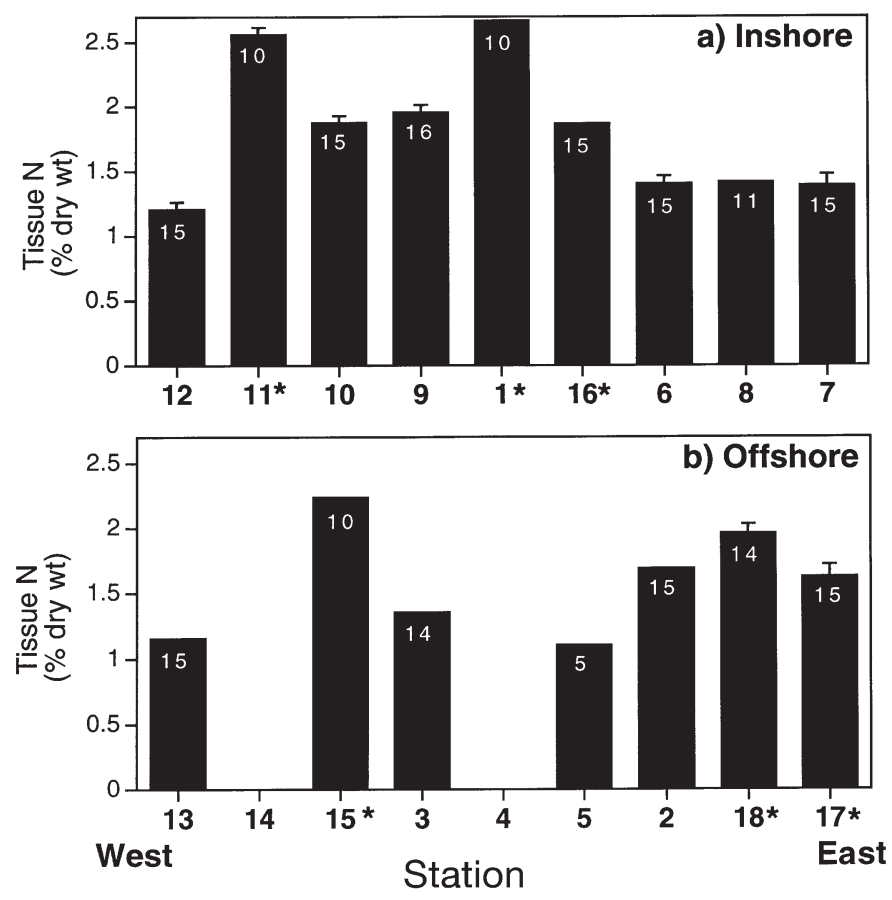

Fig. 3. Tissue $\mathrm{N}$ content of Acanthophora spicifera samples collected from each station. Stations are grouped into (a) inshore and (b) offshore sites. For both inshore and offshore groups, stations are located along the $x$-axis from east to west. White numbers within columns represent sample sizes (n) for each station and error bars $=$ SE. High Nutrient Stations (HNS) are indicated by * whether they were inshore or offshore (Fig. 3). Inshore HNS, Stn 1 (sewage ponds) and Stn 11 (low-carbonate bay), were significantly higher than all other samples (Table 4; PLSD p $<0.0005$ for all comparisons). Tissue $\mathrm{N}$ contents of $A$. spicifera from Stns 1 and 11 were $2.67 \%$ dry wt and $2.56 \%$ dry wt, respectively. These 2 stations also had high water column TKN and $\mathrm{NO}_{3}$ (Table 2) as well as sediment TKN (Table 3). The next highest tissue $\mathrm{N}(2.24 \%$ dry wt) was in algae collected in Stn 15, the offshore HNS at fishermen's island (PSLD $\mathrm{p}<0.0005)$ that also had high water column TKN and intermediate $\mathrm{NO}_{3}$ values (Table 2). The 4 means ranked next highest in tissue $\mathrm{N}$ grouped together (Table 4 ) with mean tissue $\mathrm{N}$ in station $18>$ $9>10>16$. Of these stations, 2 were identified a priori as HNS; Stn 18 is the offshore bird rookery and Stn 16 is an inshore station at the mouth of Bahia Fosforescente. Stn 18 had elevated TKN and intermediate $\mathrm{NO}_{3}$ while concentrations of both forms of $\mathrm{N}$ were lower in Stn 16. Although inshore Stns 9 and 10 were not identified a priori as HNS, they were the stations closest downcurrent from the sewage ponds and had elevated water column and sediment nitrogen (Tables 2 \& 3). With the exception of Stn 10, where $\mathrm{n}=1$, these tissue $\mathrm{N}$ rankings were the same as water column TKN and $\mathrm{NO}_{3}$ concentration rankings (Table 2). Sediment TKN was also high in Stn 9. Tissue N contents of Stns 17 and 2 also grouped together ( $p<0.02$ for all comparisons); Stn 2 was offshore of Isla Magueyez Island, which houses the marine lab, while Stn 17 was one of our offshore HNS, the sailboat anchorage. Intermediate tissue $\mathrm{N}$ values were found for inshore stations upcurrent from the town of La Parguera (Stns 6, 7 and 8) and an 
offshore reef (Stn 3). The lowest mean $\mathrm{N}$ contents (1.10 to $1.21 \%$ dry wt) were found at the inshore station most distant from the town (Stn 12) and 2 offshore reefs (Stns 5 and 13).

There were significant differences in tissue P contents of Acanthophora spicifera among stations (ANOVA p = 0.0001). As for tissue $N$, HNS had high tissue $\mathrm{P}$ regardless of whether they were inshore or offshore (Fig. 4). However, there was less statistical separation among means for tissue $\mathrm{P}$ than tissue $\mathrm{N}$ for the lower values (Table 1 ). With a few exceptions, similar groupings of stations with high $\mathrm{P}$ occurred as with high $\mathrm{N}$. Stn 1 had the highest tissue P $(0.120 \%$ dry wt; PLSD $\mathrm{p}<0.05$ ), followed by Stns 15 and 11 (0.111 and $0.102 \%$ dry wt, respectively; PSLD p < 0.0001); these were all identified a priori as HNS and had high sediment total and extractable P (Table 3) where measured. However, water column concentrations did not co-vary with tissue $\mathrm{P}$ (Table 2). Mean tissue $\mathrm{P}$ in algae
Table 3. Sediment nutrient content for sites in southwestern Puerto Rico during Sep 1998. Where $\mathrm{n}<10$, other measures are below detection limits. High Nutrient Stations (HNS) are indicated by *

\begin{tabular}{|lrcccccr|}
\hline Location & $\begin{array}{c}\text { Site } \\
\text { No. }\end{array}$ & $\begin{array}{c}\text { TKN } \\
\text { (\% dry wt) }\end{array}$ & $\mathrm{n}$ & $\begin{array}{c}\text { TP } \\
\text { (\% dry wt) }\end{array}$ & $\mathrm{n}$ & $\begin{array}{c}\text { P-Olsen } \\
(\mathrm{ppm})\end{array}$ & $\mathrm{n}$ \\
\hline Inshore $^{*}$ & 1 & $0.24(0.02)$ & 10 & $0.035(0.004)$ & 10 & $44.48(5.20)$ & 10 \\
Inshore* $^{*}$ & 11 & $0.36(0.07)$ & 10 & $0.033(0.003)$ & 10 & $48.37(8.35)$ & 10 \\
Inshore $_{\text {Inshore }}$ & 9 & $0.06(0.00)$ & 10 & - & & $27.94(4.05)$ & 10 \\
Inshore & 12 & $0.24(0.04)$ & 8 & $0.046(0.003)$ & 7 & $21.00(1.72)$ & 10 \\
Offshore* & 17 & $0.11(0.00)$ & 9 & $0.012(0.001)$ & 9 & $26.12(2.52)$ & 9 \\
Offshore & 3 & $0.03(0.00)$ & 9 & 0.025 & 2 & $34.39(1.94)$ & 10 \\
Offshore & 14 & $0.03(0.00)$ & 9 & - & & $7.32(0.69)$ & 9 \\
& & & & - & & $11.36(0.51)$ & 9 \\
\hline
\end{tabular}

from Stns 18, 16 and 17 grouped together (PLSD p < $0.0005)$ with tissue $P$ values ranging from 0.075 to $0.081 \%$ dry wt. With the exception of Stn 12, the remaining tissue $\mathrm{P}$ contents graded together, with means ranging from 0.042 to $0.061 \%$ dry wt. Mean tissue P content of $A$. spicifera from Stn 12 was significantly lower $(0.026 \%$ dry wt; PLSD p $<0.003)$ than all other stations.

Table 4. Results of Protected Least Significant Difference tests after statistically significant ANOVA. Station numbers are listed in order of increasing mean (left to right) algal tissue nutrient or ratio. Bars connect means that are not significantly different from each other

\begin{tabular}{|c|c|c|c|c|c|c|c|c|c|c|c|c|c|c|c|}
\hline \multicolumn{16}{|c|}{ Tissue N Acanthophora spicifera } \\
\hline 5 & 13 & 12 & 3 & 7 & 6 & 8 & 17 & 2 & 16 & 10 & 9 & 18 & 15 & 11 & 1 \\
\hline \multicolumn{16}{|c|}{ Tissue P Acanthophora spicifera } \\
\hline & & & & & & $=$ & 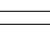 & L & & & & & & & \\
\hline 12 & 5 & 8 & 13 & 3 & 6 & 2 & 10 & 9 & 7 & 17 & 16 & 18 & 11 & 15 & 1 \\
\hline \multicolumn{16}{|c|}{ Tissue N Dictyota dichotoma } \\
\hline & & & & $=$ & & & & $\bar{E}$ & _ & & & & & & \\
\hline 12 & 10 & 6 & 5 & 7 & 2 & 11 & 15 & 13 & 4 & 3 & 1 & & & & \\
\hline \multicolumn{16}{|c|}{ Tissue P Dictyota dichotoma } \\
\hline & & - & $\bar{z}$ & & & & & & & & & & & & \\
\hline 12 & 10 & 6 & 3 & 11 & 7 & 5 & 4 & 2 & 15 & $\overline{13}$ & $\overline{1}$ & & & & \\
\hline \multicolumn{16}{|c|}{ Tissue N Halimeda incrassata } \\
\hline & & & & & $E$ & & $\overline{\overline{\bar{E}}}$ & & & & & & & & \\
\hline 18 & 16 & 12 & 9 & 15 & 8 & 2 & 13 & 6 & 7 & 17 & 1 & 11 & & & \\
\hline \multicolumn{16}{|c|}{ Tissue P Halimeda incrassata } \\
\hline & & & & & & & & & L & & & & & & \\
\hline & & & & & & & & & 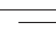 & & & & & & \\
\hline 18 & 16 & 9 & 8 & 12 & 7 & 13 & 15 & 6 & 17 & 1 & 2 & 11 & & & \\
\hline
\end{tabular}



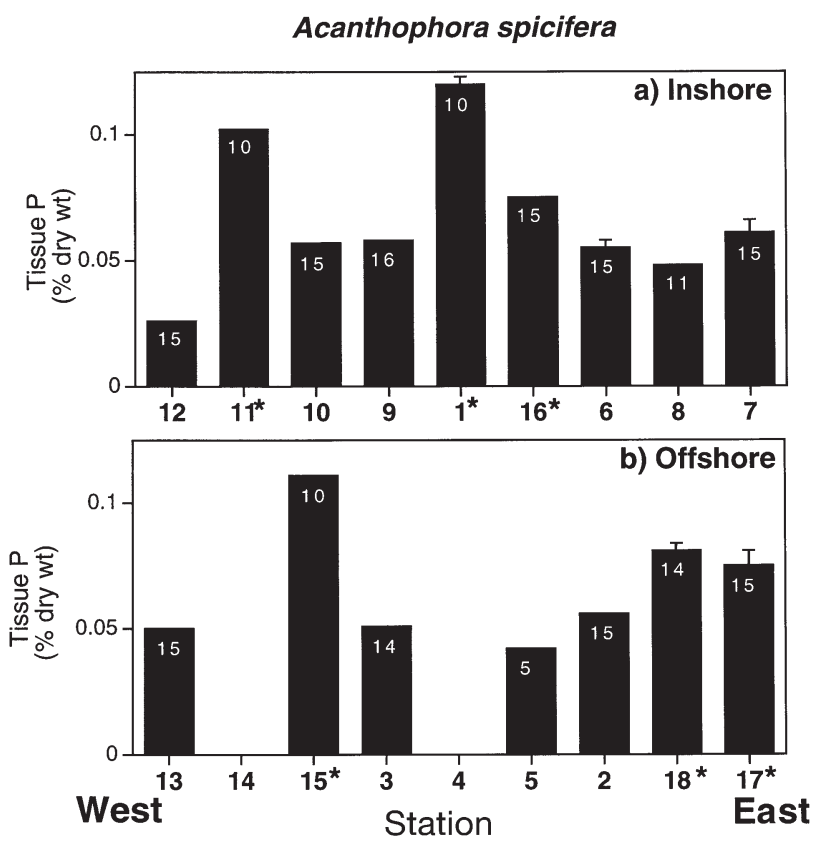

Fig. 4. Tissue P content of Acanthophora spicifera samples collected from each station. Stations are grouped into (a) inshore and (b) offshore sites. For both inshore and offshore groups, stations are located from along the $x$-axis from east to west. White numbers within columns represent sample sizes (n) for each station and error bars $=$ SE. High Nutrient Stations (HNS) are indicated by *

Mean tissue N contents for Dictyota dichotoma varied among stations (ANOVA $p=0.0001$ ), ranging from 0.81 to $2.16 \%$ dry wt (Fig. 5). Among station patterns for $D$. dichotoma were very different than for Acanthophora spicifera (Table 4). Although $D$. dichotoma tissue from Stn 1 ranked the highest in N content, it was not significantly higher than tissue collected at Stn 3, one of the offshore reefs (PLSD p > 0.05). The 7 stations ranked as highest in tissue $\mathrm{N}$ content (highest to lowest: Stns 1, 3, 4, 13, 15, 11 and 2) included all 3 of the HNS where $D$. dichotoma was collected with enough replication for statistical analysis (HNS underlined). However, they also included 3 of the 5 reef stations that were not HNS (Stns 3, 4 and 13). In addition, 4 of the 5 lowest ranked means were from inshore stations (Stns 12, 10, 6 and 7). Among these means, Stn 12 was the lowest $(0.810 \%$ dry wt).

P contents of Dictyota dichotoma also varied among stations (ANOVA $\mathrm{p}=0.0001$ ), ranging from 0.020 to $0.110 \%$ dry wt (Fig. 6, Table 4). Of the stations with enough replication for statistical analysis, Stns 1 (sewage ponds) and 13 (offshore reef) had the highest P (PLSD p $<0.01$ for all comparisons). Stations 2 (Isla Magueyez) and 15 (Fisherman's Island) had the next highest P contents (PLSD p < 0.001); both of these were also offshore sites. P contents among the rest of the stations were all lower than $0.060 \%$ dry wt. As with tissue $\mathrm{N}$, Stn 12 had the lowest P.

Halimeda incrassata, a psammophytic alga, was found more often inshore than offshore (Fig. 7). There were significant differences in tissue $\mathrm{N}$ contents among stations (ANOVA $p=0.0001$ ), although the range in tissue $\mathrm{N}(0.74$ to $1.65 \%$ dry wt) was smaller than for other species. The 3 highest ranked stations for tissue $\mathrm{N}$ of $H$. incrassata were HNS (Table 4). Stn 11 (low-carbonate bay) was significantly higher than other stations (PLSD $\mathrm{p}<0.0001$ ). Stns 1 (sewage ponds) and 17 (sailboat anchorage) grouped together as the next highest means (PLSD p $<0.001$ for all comparisons). However, other HNS such as Stns 18 (bird rookery), 16 (Bahia Fosforescente) and 15 (Fisherman's Island) had some of the lowest tissue N. Stns 18 and 15 had high water column TKN while $\mathrm{NO}_{3}$ values were the same as in non-HNS (Table 2). No sediment data were taken for these stations (Table 3). It is possible that the water column, but not the sediments, had elevated nutrients. Stns 12 and 8 had low tissue $\mathrm{N}$ for $H$. incrassata, similar to results for other species. However, Stns 6 and 7 were relatively high in tissue $\mathrm{N}$ for $H$. incrassata whereas they were low for the other species.
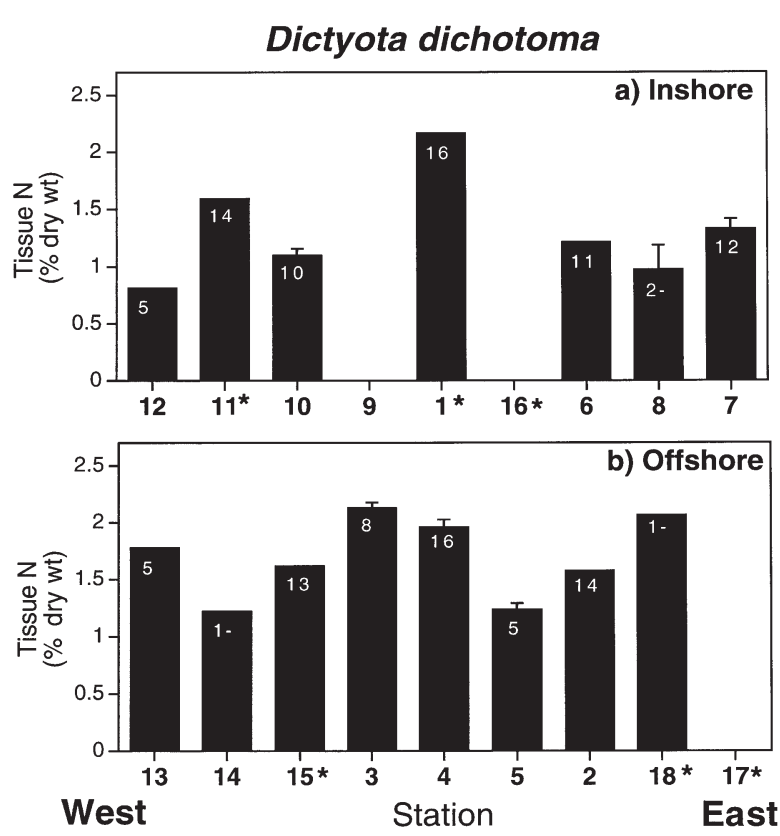

Fig. 5. Tissue N content of Dictyota dichotoma samples collected from each station. Stations are grouped into (a) inshore and (b) offshore sites. For both inshore and offshore groups, stations are located from along the $x$-axis from east to west. White numbers within columns represent sample sizes (n) for each station and error bars $=$ SE. Within column -: indicates stations with samples sizes too low to include in the ANOVA. High Nutrient Stations (HNS) are indicated by * 


\section{Dictyota dichotoma}
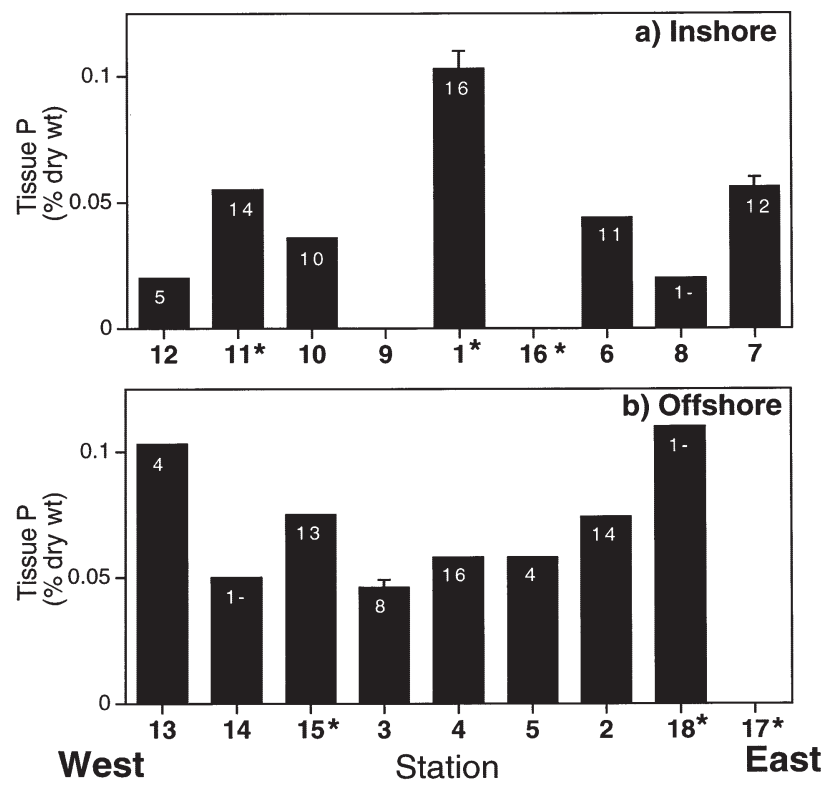

Fig. 6. Tissue P content of Dictyota dichotoma samples collected from each station. Stations are grouped into (a) inshore and (b) offshore sites. For both inshore and offshore groups, stations are located from along the $x$-axis from east to west. White numbers within columns represent sample sizes (n) for each station and error bars $=$ SE. Within column -: indicates stations with samples sizes too low to include in the ANOVA. High Nutrient Stations (HNS) are indicated by *

Tissue P contents of Halimeda incrassata (Fig. 8) varied among stations (ANOVA $\mathrm{p}=0.0001$ ), with a smaller range $(0.03$ to $0.05 \%$ dry wt) than other species. There was more overlap in means among stations for $H$. incrassata tissue $\mathrm{P}$ than for other species (Table 4). Mean $\mathrm{P}$ contents in some HNS were ranked high (Stns 11, 1 and 17) and these corresponded to stations with elevated extractable $\mathrm{P}$ in sediments. Other HNS ranked

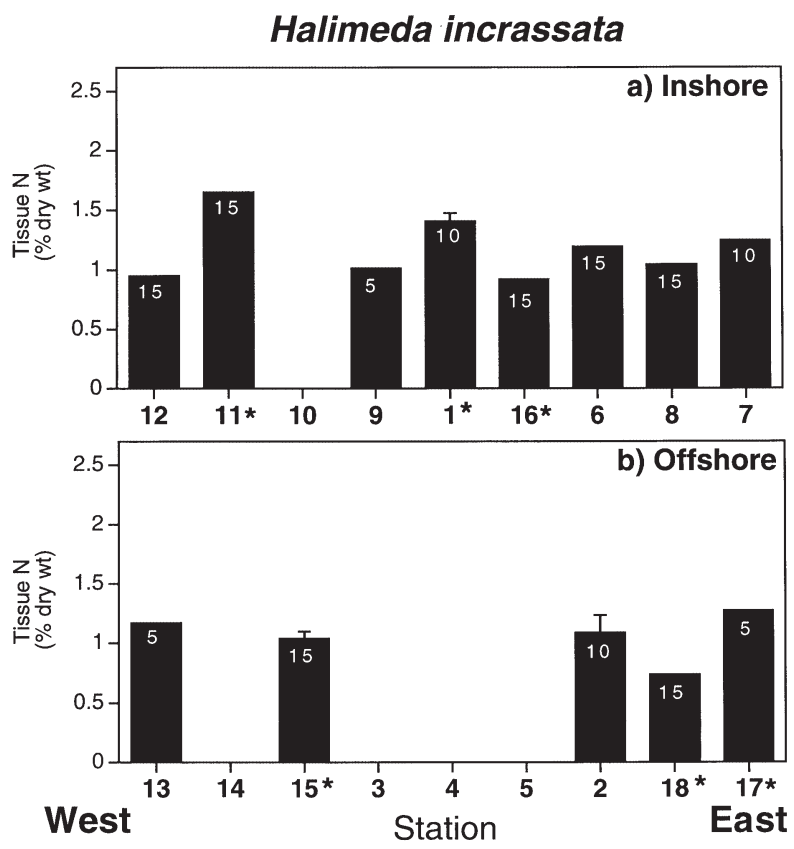

Fig. 7. Tissue N content of Halimeda incrassata samples collected from each station. Stations are grouped into (a) inshore and (b) offshore sites. For both inshore and offshore groups, stations are located from along the $x$-axis from east to west. White numbers within columns represent sample sizes (n) for each station and error bars $=$ SE. High Nutrient Stations (HNS) are indicated by *

intermediate (Stn 15) or low (Stn 18 and 16). Stn 2, off Isla Magueyez, also had high tissue $\mathrm{P}$ content for $H$. incrassata, though not for other species of algae. Sediment nutrients were not measured for these stations.

There were significant differences in tissue $\mathrm{N}$ of Dictyota cervicornis among stations (Table 5; ANOVA p = $0.0001)$; patterns were similar to $D$. dichotoma. Although tissue N contents of samples from Stns 15, 11

\section{Halimeda incrassata}
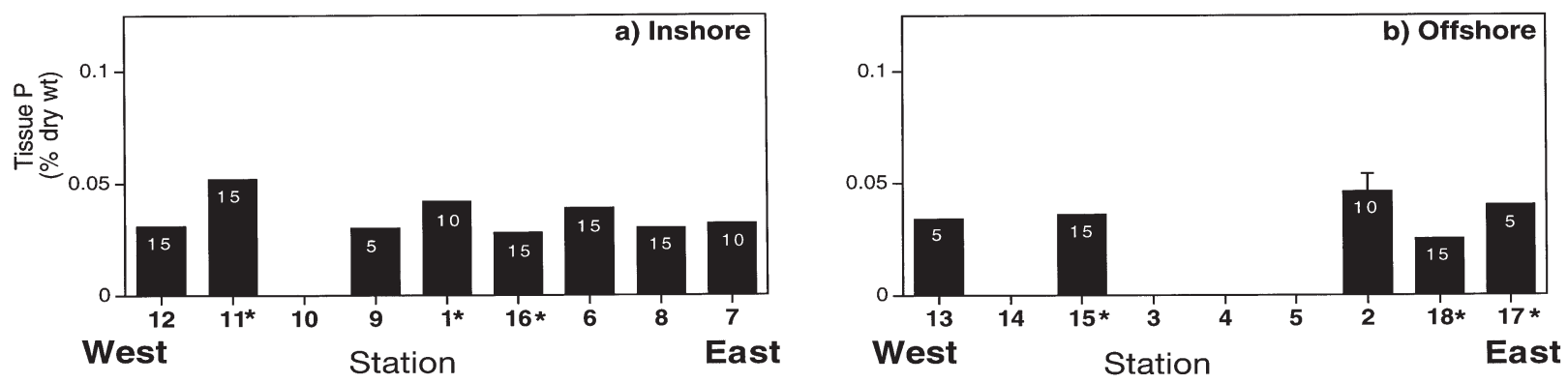

Fig. 8. Tissue P content of Halimeda incrassata samples collected from each station. Stations are grouped into (a) inshore and (b) offshore sites. For both inshore and offshore groups, stations are located from along the $x$-axis from east to west. White numbers within columns represent sample sizes (n) for each station and error bars = SE. High Nutrient Stations (HNS) are indicated by * 
and 16 (HNS) all ranked among the higher means, so did 2 reef stations (Stns 13 and 14). Replication at Stn 1 was not sufficient to be used in this analysis. Stn 12 ranked lowest in tissue $\mathrm{N}$ content, consistent with the other species of algae.

There were also differences in tissue $\mathrm{P}$ contents for Dictyota cervicornis among stations (ANOVA $\mathrm{p}=$ 0.0001). There was much more separation in mean tissue $\mathrm{P}$ content than $\mathrm{N}$ (Table 5). Highest tissue P was found in algae from Stn 15, a HNS, while the second highest value was from Stn 13, a reef site. Stn 11, another HNS, was ranked low in tissue P. Consistent with results for other species, Stn 12 ranked lowest in tissue P.

Hypnea musciformis was only found in sufficient quantity to collect in 5 of 18 stations; of these, 4 were inshore (Table 5). H. musciformis tissue $\mathrm{N}$ and $\mathrm{P}$ contents were different among stations (ANOVA $\mathrm{p}=$ 0.0001 for both nutrients). Stn 1 ranked highest in tissue $N$ (PLSD p $<0.001$ for all comparisons) while the reef station (Stn 13) ranked the lowest. As for N, Stn 1 ranked highest in tissue $\mathrm{P}$ (PLSD $\mathrm{p}<0.001$ for all comparisons). However, (Stn 13) the reef station ranked second highest in tissue $\mathrm{P}$, though $\mathrm{n}=3$ for this station.

\section{Correlation between water column, sediment, and tissue nutrients}

There were several significant correlations between water column and sediment nutrients (Table 6). Water column TKN correlated with sediment total $\mathrm{P}$ and water $\mathrm{NO}_{3}$ concentration correlated with both TKN and extractable $\mathrm{P}$ in the sediment. In contrast, total $\mathrm{P}$ in the water did not correlate with any sediment measure.

Nitrogen in the water column (TKN and $\mathrm{NO}_{3}$ ) correlated with both $\mathrm{N}$ and $\mathrm{P}$ in the tissue of Acanthophora spicifera (Table 6). Water total $\mathrm{P}$ and $\mathrm{NO}_{3}$ correlated with $\mathrm{N}$ and $\mathrm{P}$ in Halimeda incrassata tissue. In contrast, neither N nor P in the tissue of either species of Dictyota correlated with any measure of nutrients in the water. Tissue nutrients of Hypnea musciformis did not correlate with water column nutrients, probably due to the limited statistical power associated with low sample size.

Sediment TKN correlated with tissue $\mathrm{N}$ of Acanthophora spicifera while extractable $\mathrm{P}$ in sediments correlated with both tissue $\mathrm{N}$ and $\mathrm{P}$ (Table 6). Tissue $\mathrm{N}$ and $\mathrm{P}$ of Halimeda incrassata correlated with extractable P in the sediments. Neither Dictyota had any significant relationship with sediment nutrients.

Table 5. Results of Protected Least Significant Difference (PLSD) tests after statistically significant ANOVA. Stations are listed in order of increasing means (left to right) of algal tissue nutrient or ratio. Bars connect means that are not significantly different from each other. Means, SE, and $n$ are listed below stations

\begin{tabular}{|c|c|c|c|c|c|c|c|c|c|c|}
\hline \multicolumn{4}{|c|}{ Tissue N Dictyota cervicornis } & \multirow[b]{2}{*}{7} & \multirow[b]{2}{*}{11} & \multirow[b]{2}{*}{16} & \multirow[b]{2}{*}{13} & \multirow[b]{2}{*}{1} & \multirow[b]{2}{*}{14} & \multirow[b]{2}{*}{15} \\
\hline Stn & 12 & 6 & 5 & & & & & & & \\
\hline Mean & 0.86 & 1.15 & 1.29 & 1.43 & 1.55 & 1.58 & 1.68 & 1.71 & 1.73 & 1.78 \\
\hline SE & 0.03 & 0.05 & 0.08 & 0.04 & 0.03 & 0.03 & 0.16 & 0.01 & & \\
\hline $\mathrm{n}$ & 10 & 6 & 8 & $1^{*}$ & 5 & 10 & 8 & $1^{*}$ & 7 & 11 \\
\hline \multicolumn{4}{|c|}{ Tissue P Dictyota cervicornis } & & & & & & & \\
\hline Stn & 12 & 6 & 11 & 5 & 14 & 16 & 1 & 13 & 15 & \\
\hline Mean & 0.027 & 0.042 & 0.046 & 0.060 & 0.073 & 0.086 & 0.090 & 0.96 & 0.127 & \\
\hline $\mathrm{SE}$ & 0.002 & 0.002 & 0.002 & 0.004 & 0.005 & 0.002 & 0.003 & 0.002 & & \\
\hline $\mathrm{n}$ & 10 & 6 & 5 & 8 & 7 & 10 & $1^{*}$ & 8 & 10 & \\
\hline \multicolumn{4}{|c|}{ Tissue N Hypnea musciformis } & & & & & & & \\
\hline Stn & 13 & 12 & 9 & 10 & 1 & & & & & \\
\hline Mean & 1.09 & 1.44 & 1.49 & 1.68 & 2.03 & & & & & \\
\hline $\mathrm{SE}$ & 0.06 & 0.09 & 0.02 & 0.04 & 0.02 & & & & & \\
\hline $\mathrm{n}$ & 4 & 10 & 10 & 10 & 5 & & & & & \\
\hline \multicolumn{5}{|c|}{ Tissue P Hypnea musciformis } & & & & & & \\
\hline Station & 12 & 9 & 10 & 13 & 1 & & & & & \\
\hline Mean & 0.039 & 0.045 & 0.059 & 0.067 & 0.088 & & & & & \\
\hline SE & 0.002 & 0.002 & 0.003 & 0.003 & 0.002 & & & & & \\
\hline $\mathrm{n}$ & 9 & 10 & 10 & 3 & 5 & & & & & \\
\hline
\end{tabular}




\section{DISCUSSION}

Our results support the hypothesis that tissue nitrogen content of erect algae with open branches is a good indicator of water column nitrogen concentration. Acanthophora spicifera had higher $\mathrm{N}$ content inshore compared to offshore, reflecting water column TKN and $\mathrm{NO}_{3}$ concentrations. A. spicifera also had higher tissue $\mathrm{N}$ content in samples collected at High Nutrient Stations (HNS) with elevated water column nitrogen concentrations. In addition, both water column and tissue nitrogen were high in a station that had not been identified a priori, but was just downcurrent of a nutrient source. Although replication was low, Hypnea musciformis, another species with open branches, followed the same pattern. Similar results have been found in both laboratory and field studies. In a laboratory experiment, Pedersen \& Borum (1997) found that a branching red alga took up nutrients in proportion to water column concentration across a wider range of $\mathrm{N}$ supply than slower growing, more fleshy forms of algae. Field studies suggest tissue nutrients in excess of minimum concentrations for growth in branching red algae can be used to assess water quality (Lyngby 1990, Lyngby \& Mortensen 1994). Fong et al. (1998) related nutrient supply to the tissue $\mathrm{N}$ content of floating mats of green macroalgae tethered along a nutrient gradient in an estuary.

In contrast to the pattern found for tissue N, tissue P of Acanthophora spicifera did not reflect water column P concentrations. Although tissue $\mathrm{P}$ was higher inshore than offshore, and highest in HNS, water column $\mathrm{P}$ concentration did not follow this pattern. Evidence is accumulating that $\mathrm{P}$ may limit primary productivity and growth of tropical marine algae in shallow carbonate systems (Lapointe et al. 1987, 1992, Littler et al. 1991). If so, then $P$ may be rapidly depleted from the water by biological uptake as well as adsorption to the sediment, resulting in low water column concentrations despite variability in supply. Fong et al. (1994) found a strong relationship between nutrient supply, water column nutrients, and tissue nutrients for the nutrient (in this case, N) that was not in limiting supply. This suggests that
Table 6. Correlations between water column nutrients, sediment nutrients and tissue $N$ and P. Numbers are R, values in bold are significant $(p<0.05)$. For values denoted with ${ }^{*} \mathrm{p}$ is between 0.05 and 0.10 . Number in parentheses $=n$

\begin{tabular}{|c|c|c|c|}
\hline Water column and & $\begin{array}{l}\text { ent nutrients } \\
\text { Water TKN }\end{array}$ & Water TP & Water $\mathrm{NO}_{3}$ \\
\hline Sediment TKN & $0.650^{*}(8)$ & $0.557(6)$ & $0.771(8)$ \\
\hline Sediment TP & $0.888(5)$ & $0.053(4)$ & $0.220(5)$ \\
\hline Sediment P-Olsen & $0.704^{*}(8)$ & $0.605(6)$ & $0.822(8)$ \\
\hline \multicolumn{4}{|c|}{ Water column nutrients and tissue nutrients } \\
\hline & Water TKN & Water TP & Water $\mathrm{NO}_{3}$ \\
\hline \multicolumn{4}{|c|}{ Acanthophora spicifera } \\
\hline Tissue N & $0.525(16)$ & $0.340(15)$ & $0.759(16)$ \\
\hline Tissue $\mathrm{P}$ & $0.520(16)$ & $0.073(15)$ & $0.736(16)$ \\
\hline \multicolumn{4}{|l|}{ Halimeda incrassata } \\
\hline Tissue N & $0.122(13)$ & $0.589(12)$ & $0.730(13)$ \\
\hline Tissue $\mathrm{P}$ & $0.123(13)$ & $0.843(12)$ & $0.650(13)$ \\
\hline \multicolumn{4}{|l|}{ Dictyota dichotoma } \\
\hline Tissue N & 0.107 (15) & $0.273(13)$ & $0.345(15)$ \\
\hline Tissue $\mathrm{P}$ & $0.061(15)$ & $0.215(13)$ & $0.286(15)$ \\
\hline \multicolumn{4}{|l|}{ Dictyota cervicornis } \\
\hline Tissue N & $0.141(10)$ & $0.089(8)$ & $0.300(10)$ \\
\hline Tissue $\mathrm{P}$ & $0.068(9)$ & $0.650(7)$ & $0.036(9)$ \\
\hline \multicolumn{4}{|l|}{ Hypnea musciformis } \\
\hline Tissue N & $0.642(5)$ & $0.861(4)$ & $0.764(5)$ \\
\hline Tissue $\mathrm{P}$ & $0.228(5)$ & $0.024(4)$ & $0.805^{*}(5)$ \\
\hline \multicolumn{4}{|c|}{ Sediment nutrients and tissue nutrients } \\
\hline & Sediment TKN & Sediment TP & P-Olsen \\
\hline \multicolumn{4}{|c|}{ Acanthophora spicifera } \\
\hline Tissue N & $0.826(8)$ & $0.652(5)$ & $0.799(8)$ \\
\hline Tissue $\mathrm{P}$ & $0.580(8)$ & $0.491(5)$ & $0.768(8)$ \\
\hline \multicolumn{4}{|l|}{ Halimeda incrassata } \\
\hline Tissue N & $0.529(6)$ & $0.239(5)$ & $0.943(6)$ \\
\hline Tissue $\mathrm{P}$ & $0.445(6)$ & $0.108(5)$ & $0.917(6)$ \\
\hline \multicolumn{4}{|l|}{ Dictyota dichotoma } \\
\hline Tissue N & $0.115(6)$ & $0.937(3)$ & $0.128(6)$ \\
\hline Tissue $\mathrm{P}$ & $0.324(6)$ & $0.860(3)$ & $0.492(6)$ \\
\hline \multicolumn{4}{|l|}{ Dictyota cervicornis } \\
\hline Tissue $\mathrm{N}$ & $0.133(5)$ & $0.995^{*}(3)$ & $0.170(5)$ \\
\hline Tissue $\mathrm{P}$ & $0.047(5)$ & $0.784(3)$ & $0.089(5)$ \\
\hline
\end{tabular}

P may be limiting primary productivity in southwestern Puerto Rico.

Our results provide some evidence to support the hypothesis that rhizophytic algae have higher tissue $\mathrm{P}$ where sediment $\mathrm{P}$ content is higher. Halimeda incrassata had higher tissue $\mathrm{P}$ inshore and in stations where extractable $P$ was highest, resulting in a significant correlation between these measures. It has been documented that Caulerpa cupressoides, a siphonous green alga with rhizoids, translocates sediment nutrients to photosynthetic portions of the thallus (Williams 1981). Rhizophytic algae from inshore areas of Kaneohe Bay with high sediment nutrient content were able to sus- 
tain positive growth despite low water column nutrient concentrations (Larned \& Stimson 1997). Others have found that sustained high levels of nutrient loading into a tropical system resulted in enriched sediments and more nutrients being biologically available (McGlathery et al. 1994, Corredor et al. 1999). However, more quantification of sediment nutrients is needed in order for our study to support this hypothesis fully, as we had little data for sediments with low P content. In addition, in the stations where sediment $\mathrm{P}$ was low (offshore), Halimeda incrassata was absent. Although high tissue $\mathrm{P}$ content in Halimeda incrassata corresponded with extractable sediment $\mathrm{P}$, tissue $\mathrm{N}$ and $\mathrm{P}$ content was also related to water column nutrient content. This suggests that $H$. incrassata may also rely on water column nutrient sources. However, high water column and sediment $\mathrm{N}$ and $\mathrm{P}$ co-varied in HNS, potentially confounding the relationships. It is possible that transplant experiments may aid in understanding the relative importance of these 2 sources of nutrients.

Tissue nutrients in algae that form tightly compacted mats were not higher in HNS, and did not show any patterns relating to any measure of either water column or sediment nutrients. Tissue $\mathrm{N}$ and $\mathrm{P}$ contents for both species of Dictyota were higher offshore, where sediment and water column nutrient concentrations were lowest. In another study, dense mats of a benthic green alga were found to strip all nutrients from the water within the mat, resulting in nutrient depletion of upper layers of the mat (McGlathery et al. 1997). Dictyosphaeria cavernosa, a mat-forming species of green algae common in Kaneohe Bay, Hawaii, requires high rates of advection to sustain growth in offshore sites with low water column and sediment nutrient sources (Larned \& Atkinson 1997). We suggest that the pattern of higher tissue nutrients in mat-forming algae collected offshore may be explained by higher rates of advection.

Our data suggest N:P ratios alone may not be a good indicator of nutrient supply. The same pattern of higher $\mathrm{N}: \mathrm{P}$ ratio inshore was found for Acanthophora spicifera, Halimeda incrassata, and Dictyota cervicornis. Using only N:P ratio as an indicator of nutrient supply, one would conclude that $\mathrm{N}$ was more plentiful inshore than offshore for all species. However, the source of this inshore/offshore pattern differed among the species of algae. For A. spicifera and $H$. incrassata, higher N:P ratios were due to high $\mathrm{N}$ contents inshore, supporting the hypothesis of an inshore $\mathrm{N}$ source. In contrast, for $D$. cervicornis both $\mathrm{N}$ and $\mathrm{P}$ contents were higher offshore, suggesting an offshore source of both nutrients. The higher N:P ratio inshore was simply due to the much greater differential between $\mathrm{P}$ values compared to $\mathrm{N}$ values inshore vs offshore. Thus, N:P ratios must be used in conjunction with tissue values to determine nu- trient status of macroalgae (Björnsäter \& Wheeler 1990, Wheeler \& Björnsäter 1992, Fong et al. 1994, 1998).

Our results suggest that the tissue $\mathrm{N}$ and $\mathrm{P}$ content of macroalgae may be a good indicator of the various sources of nutrients biologically available to primary producers in tropical marine systems. To be a good indicator, tissue $\mathrm{N}$ and $\mathrm{P}$ content must be a plastic trait that is determined, at least in part, by nutrient availability. This seems to be true for all species collected. Tissue $\mathrm{N}$ and $\mathrm{P}$ varied between inshore and offshore areas and among specific stations, suggesting nutrient content is controlled by environmental factors. Although a suite of environmental factors such as light and temperature are known to influence the tissue $\mathrm{N}$ and $\mathrm{P}$ content of macroalgae, our data show that nutrient availability is also very important, as tissue $\mathrm{N}$ and $\mathrm{P}$ varied with water column and sediment supplies for non mat-forming species. Others have demonstrated that nutrient availability can be estimated by macroalgal tissue $\mathrm{N}$ and $\mathrm{P}$ content in temperate environments (Lyngby 1990, Lyngby \& Mortensen 1994, Fong et al. 1998) provided that variance in light and temperature are carefully controlled. Our findings suggest that if other environmental factors are taken into consideration, tissue $\mathrm{N}$ and $\mathrm{P}$ contents may prove to be effective indicators in tropical systems as well.

Acknowledgements. This work was funded by the Academic Senate of UCLA and by the US Environmental Protection Agency (Project 021925 to P.F.). Our deepest thanks to Ernesto Weil at the University of Puerto Rico for hosting us in his laboratory and for his advice and help with logistics.

\section{LITERATURE CITED}

Alves De Guimaraens M, Coutinho R (1996) Spatial and temporal variation of benthic marine algae at the Cabo Frio upwelling region, Rio de Janeiro, Brazil. Aquat Bot 52: 283-299

Atkinson MJ, Bilger RW (1992) Effects of water velocity on phosphate uptake in coral reef-flat communities. Limnol Oceanogr 37:273-279

Atkinson MJ, Smith SV (1983) C:N:P ratios of benthic marine plants. Limnol Oceanogr 28:568-574

Baird ME, Atkinson MJ (1997) Measurement and prediction of mass transfer to experimental coral reef communities. Limnol Oceanogr 42:1685-1693

Beach KS, Smith CM (1997) Ecophysiology of a tropical rhodophyte III: Recovery from emersion stresses in Ahnfeltiopsis concinna (J. Ag.) silva et DeCew. J Exp Mar Biol Ecol 211:151-167

Bischoff-Baesmann B, Bartsch I, Xia B, Weincke C (1997) Temperature responses from the tropical island Hainan (PR China). Phycol Res 45:91-104

Björnsäter BR, Wheeler PA (1990) Effect of nitrogen and phosphorus supply on growth and tissue composition of Ulva fenetrata and Enteromorpha intestinalis (Ulvales, Chlorophyta). J Phycol 26:603-611

Boynton W, Kemp W, Keefe C (1982) A comparative analysis of nutrients and other factors influencing estuarine phyto- 
plankton production. In: Kennedy V (ed) Estuarine comparisons. Academic Press, New York, p 69-90

Breyer JA, Ehlmann AJ (1981) Mineralogy of arc-derived sediment: siliclastic sediment on the insular shelf of Puerto Rico. Sedimentology 28:61-74

Cadée GC, Hegeman J (1993) Persisting high levels of primary production at declining phosphate concentrations in the dutch coastal area (Marsdiep). Neth J Sea Res 31: $147-152$

Carpenter RC (1986) Partitioning herbivory and its effects on coral reef algal communities. Ecol Monogr 56:345-363

Carlson RM (1978) Automated separation and conductimetric determination of ammonia and dissolved carbon dioxide. Anal Chem 50:1528-1531

Corredor JE, Morell JM (1994) Nitrate depuration of secondary sewage effluents in mangrove sediments. Estuaries 17:295-300

Corredor JE, Howarth RW, Twilley RW, Morell JM (1999) Nitrogen cycling and anthropogenic impact in the tropical interamerican seas. Biogeochem 46:163-178

Delgado O, Lapointe BE (1994) Nutrient-limited productivity of calcareous versus fleshy macroalgae in a eutrophic, carbonate-rich tropical marine environment. Coral Reefs 13: 151-159

Diaz MC, Ward BB (1997) Sponge-mediated nitrification in tropical benthic communities. Mar Ecol Progr Ser 156: 97-107

Downing JA, McClain M, Twilley RW, Melack JM, Elser J, Rabalais NN, Lewis WM, Turner RE, Corredor J, Soto D, Yanez-Arancibia A, Kopaska JA, Howarth RW (1999) The impact of accelerating land-use change on the $\mathrm{N}$-cycle of tropical aquatic ecosystems: current conditions and projected changes. Biogeochem 46:109-148

Fong P, Boyer KE, Zedler JB (1998) Developing an in situ bioassay of nutrient enrichment in coastal estuaries and lagoons using tissue nitrogen content of the opportunistic alga, Enteropmorpha intestinalis. J Exp Mar Biol Ecol 231: 63-79

Fong P, Donohoe RM, Zedler JB (1994) Nutrient concentration in tissue of the macroalga Enteromorpha spp. as an indicator of nutrient history: an experimental evaluation using field microcosms. Mar Ecol Prog Ser 106:273-281

Franson MAH (1985) Method 424-F. In: Standard methods for the examination of water and wastewater. 16th edn, APHA, AAWA, and WPCF, Washington, DC, p 448-450

Genin A, Lazar B, Brenner S (1995) Vertical mixing and coral death in the Red Sea following the eruption of Mount Pinatubo. Nature 377:507-510

Hanisak MD (1983) The nitrogen relationships of marine macroalgae. In: Carpenter EJ, Capone DG (eds) Nitrogen in the marine environment. Academic Press, New York

Hanisak MD, Harlin MM (1978) Uptake of inorganic nitrogen by Codium fragile subsp. tomentosoides (Chlorophyta). J Phycol 14:450-454

Hatcher BG, Larkum AWD (1983) An experimental analysis of factors controlling the standing crop of the epilithic algal community on a coral reef. J Exp Mar Bio Ecol 69:61-84

Horrocks JL, Stewart GR, Dennison WC (1995) Tissue nutrient content of Gracilaria spp (Rhodophyta) and water quality along an estuarine gradient. Mar Freshw Res 46:975-983

Howarth RW (1988) Nutrient limitation of net primary production in marine systems. Annu Rev Ecol Syst 19:89-110

Hughes TP (1989) Community structure and diversity of coral reefs: the role of history. Ecology 70:275-279

Issac RA, Johnson WC (1976) Determination of total nitrogen in plant tissue, using a block digestor. J Assoc Anal Chem 59:98-100
Jaworski NA, Howarth RW, Hetling LJ (1997) Atmospheric deposition of nitrogen oxides onto the landscape contributes to coastal eutrophication in the Northeast United States. Environ Sci Technol 31:1995-2004

Johnson CM, Ulrich A (1959) Analytical methods for use in plant analysis. In: Bulletin 766. Agricultural Experimental Station, University of California, Berkeley, p 26-78

Knoppers B, Landim De Souza WF, Landim De Souza MF, Rodriquez EG, Landim EDFDCV, Vieira AR (1996) In situ measurements of benthic primary production, respiration and nutrient fluxes in a hypersaline coastal lagoon of SE Brazil. Rev Bra Oceanogr 44:155-165

Kress N, Herut D (1998) Hypereutrophication in the oligotrophic Eastern Mediterranean: a study in Haifa Bay (Israel). Estuar Coast Shelf Sci 46:645-656

Lapointe BE (1987) Phosphorus- and nitrogen-limited photosynthesis and growth of Gracilaria tikvahiae (Rhodophyceae) in the Florida Keys: an experimental field study. Mar Biol 93:561-568

Lapointe BE, O'Connell J (1989) Nutrient-enhanced growth of Cladophora prolifera in Harrington Sound, Bermuda: eutrophication of a confined, phosphorus-limited marine ecosystem. Estuar Coast Shelf Sci 28:347-360

Lapointe BE, Littler MM, Littler DS (1987) A comparison of nutrient-limited productivity in macroalgae from Caribbean barrier reef and from mangrove ecosystem. Aquat Bot 28:243-255

Lapointe BE, Littler MM, Littler DS (1992) Nutrient availability to marine macroalgae in siliciclastic versus carbonaterich coastal waters. Estuaries 15:75-82

Lapointe BE, Littler MM, Littler DS (1997) Macroalgal overgrowth of fringing coral reefs at Discovery Bay, Jamaica: bottom up versus top-down control. Proc 8th Int Coral Reef Symp 1:927-932

Larned ST (1998) Nitrogen- versus phosphorus-limited growth and sources of nutrients for coral reef macroalgae. Mar Biol 132:409-421

Larned ST, Atkinson MJ (1997) Effects of water velocity on NH4 and PO4 uptake and nutrient-limited growth in the macroalga Dictyosphaeria cavernosa. Mar Ecol Prog Ser 157:295-302

Larned ST, Stimson J (1997) Nitrogen-limited growth in the coral reef chlorophyte Dictyosphaeria cavernosa, and the effect of exposure to sediment-derived nitrogen on growth. Mar Ecol Prog Ser 145:95-108

Littler DS, Littler MM (2000) Caribbean Reef Plants. Offshore Graphics, Washington, DC

Littler DS, Littler MM, Bucher KE, Norris JN (1989) In: Atherton A (ed) Marine Plants of the Caribbean A Field Guide from Florida to Brazil. Smithsonian Institution Press, Washington, DC

Littler DS, Littler MM, Titlyanov EA (1991) Comparisons of Nand P-limited productivity between high granatic islands vs. low carbonate atolls in the Seychelles Archipelago: a test of the relative-dominance paradigm. Coral Reefs 10: 199-209

Littler MM, Littler DS (1980) The evolution of thallus form and survival strategies in benthic marine macroalgae: field and laboratory tests of a functional form model. Am Nat 115:25-43

Littler MM, Littler DS (1985) Factors controlling relative dominance of primary producers on biotic reefs. Proc 5th Int Coral Reef Symp 4:35-39

Lyngby JE (1990) Monitoring of nutrient availability and limitation using the marine macroalga Ceramium rubrum (Huds.) C. Ag. Aquat Bot 38:153-162

Lyngby JE, Mortensen SM (1994) Assessment of nutrient 
availability and limitation using macroalgae. J Aquat Ecosyst Health 3:27-34

McCook LJ (1999) Macroalgae, nutrients and phase shifts on coral reefs: scientific issues and management consequences for the Great Barrier Reef. Coral Reefs 18:357-367

McGlathery KJ, Marino R, Howarth RW (1994) Variable rates of phosphorus uptake by shallow marine carbonate sediments: mechanisms and ecological significance. Biogeochem 25:127-146

McGlathery KJ, Krause-Jensen D, Rysgaard S, Christensen PB (1997) Patterns of ammonium uptake within dense mats of the filamentous macroalga Chaetomorpha linum. Aquat Bot 59:99-115

Morelock J, Schneidermann N, Bryant WR (1977) Shelf reefs, southwestern Puerto Rico. In: Frost SH, Weiss MP, Saunders JB (eds) Studies in Geology, 4. AAPG, Tulsa, OK, p $17-25$

Nixon SW, Ammerman JW, Atkinson LP, Beroundsky VM, and 12 others (1996) The fate of nitrogen and phosphorus at the land-sea margin of the North Atlantic Ocean. Biogeochemistry 35:141-180

Odum HT, Burkholder PR, Rivero J (1959) Measurements of productivity of turtle grass flats, reefs, and the Bahia Fosforescente of southern Puerto Rico. Pubs Inst Mar Sci Univ Tex 6:159-170

Olsen SR, Cole CV, Watanabe FS, Dean LA (1954) Estimation of available phosphorus in soils by extraction with sodium bicarbonate. U S Dept Agric Circ 939:119

Pedersen MF, Borum J (1997) Nutrient control of estuarine macroalgae: growth strategy and the balance between nitrogen requirements and uptake. Mar Ecol Prog Ser 161: 155-163

Powell GVN, Kenworthy WJ, Fourqurean JW (1989) Experimental evidence for nutrient limitation of seagrass growth in a tropical estuary with restricted circulation. Bull Mar Sci 44:324-340

Rafalska-Bloch J (1985) Organic facies of modern sediments in reefal environments of southwestern Puerto Rico and Northern Belize. Proc 5th Int Coral Reef Congress 3: 383-388

Rosenburg G, Ramus J (1984) Uptake of inorganic nitrogen and seaweed surface area:volume ratios. Aquat Bot 19: $65-72$

Russ GR, McCook LJ (1999) Potential effects of a cyclone on benthic algal production and yield to grazers on coral reefs across the central great Barrier Reef. J Exp Mar Biol Ecol 235:237-254

Sah RN, Miller RO (1992) Spontaneous reaction for acid dissolution of biological tissues in closed vessels. Anal Chem 64:230-233

Editorial responsibility: Charles Birkeland (Contributing Editor), Hawaii, Honolulu, USA
Schaffelke B, Klumpp DW (1997) Growth of germlings of the macroalga Sargassum baccularia (Phaeophyta) is stimulated by enhanced nutrients. Proc 8th Int Coral Reef Symp 2:1839-1842

Schaffelke B, Klumpp DW (1998a) Nutrient-limited growth of the coral reef the macroalga Sargassum baccularia and experimental growth enhancement by nutrient addition in continuous flow culture. Mar Ecol Prog Ser 164: $199-211$

Schaffelke B, Klumpp DW (1998b) Short-term nutrient pulses enhance growth and photosynthesis of the coral reef macroalga Sargassum baccularia. Mar Ecol Prog Ser 170: 95-105

Steneck RS, Watling L (1982) Feeding capabilities and limitation of herbivorous Molluscs: A functional group approach. Mar Biol 68:299-319

Sweeney RA (1989) Generic combustion method for determination of crude protein in feeds: a collaborative study. J Assoc Anal Chem 72:770-774

Szmant AM (1997) Nutrient effects on coral reefs: a hypothsis on the importance of topographic and trophic complexity to reef nutrient dynamics. Proc 8th Int Coral Reef Symp 2: $1527-1532$

Tanner JE (1995) Competition between scleractinian corals and macroalgae: an experimental investigation of coral growth, survival, and reproduction. J Exp Mar Biol Ecol 190:151-168

Thomas FIM, Atkinson MJ (1997) Ammonium uptake by coral reefs: effects of water velocity and surface roughness on mass transfer. Limnol Oceanogr 42:81-88

Powell GVN, Kenworthy WJ, Fourqurean JW (1989). Experimental evidence for nutrient limitation of seagrass growth in a tropical estuary with restricted circulation. Bull Mar Sci 44:324-340

Uthicke S, Klumpp DW (1998) Microphytobenthos community production at a near-shore coral reef: Seasonal variation and response to ammonium recycled by holothurians. Mar Ecol Prog Ser 169:1-11

Vitousek PM, Aber JD, Howarth RW, Likens GE, Matson PA, Schindler DW, Schlesinger WH, Tilman DG (1997) Human alteration of the global nitrogen cycle: source and consequences. Ecol Appl 7:737-750

Wheeler PA, Björnsäter BR (1992) Seasonal fluctuations in tissue nitrogen, phosphorus, and N:P for five macroalgal species common to the Pacific northwest coast. J Phycol $28: 1-6$

Williams SL (1981) Caulerpa cupressoides: the relationship of the uptake of sediment ammonium and of algal decomposition to seagrass bed colonization. $\mathrm{PhD}$ thesis, University of Maryland

Submitted: September 6, 2000; Accepted: February 11, 2001

Proofs received from author(s): September 4, 2001 